\title{
Leaf and calycine colleters in Odontadenia lutea (Apocynaceae - Apocynoideae - Odontadenieae): their structure and histochemistry ${ }^{1}$
}

\author{
FABIANO MACHADO MARTINS ${ }^{2,3}$
}

(received: April 18, 2011; accepted: December 7, 2011)

\begin{abstract}
Leaf and calycine colleters in Odontadenia lutea (Apocynaceae - Apocynoideae - Odontadenieae): their structure and histochemistry). The structure and histochemistry of colleters found on the vegetative and floral apices of Odontadenia lutea are described. Colleters occur on vegetative apices starting at the fourth node, with 68 to 80 colleters being found at each node. Each leaf primordium has only one colleter of axillary origin, 3-5 intra-petiolar, and 12-16 inter-petiolar (intra-stipular). There are four types of colleters: standard, bipartite standard, sessile, and bipartite sessile. Colleters on the reproductive apices alternate with the sepals and are sessile, reduced sessile, tripartite laminar sessile, or asymmetrical. All of the colleters have a central nucleus of parenchymatous cells covered by a palisade uniseriate secretory epidermis and a thin cuticle. Secretory idioblasts were observed in the parenchymatous axis. Vascularization was observed only in standard axillary and laminar colleters. Crystals were observed in the parenchyma of the axillary colleter. Histochemical tests demonstrated that there was no rupturing or distension of the cuticle during the secretion process. Mucilage was identified using the PAS reaction as well as by Mayer's reagent and Ruthenium red staining. The calycine colleters had two distinct secretory phases, the first synthesizing mucilage and the second producing phenolic compounds.
\end{abstract}

Key words - mucilage, phenolic compounds, secretory structures

\section{INTRODUCTION}

Secretory structures vary widely in terms of their morphology, position, function, and types of secretion (Fahn 1979). Accordingly, studies of the chemical composition of the secreted materials and anatomical characterizations of colleters are needed to fully understand their roles and the functions of their exudates (Schnepf 1974). Additionally, histochemical studies are needed to detect the principal metabolites that compose the exudates, as the identification of secretory structures is largely based on the predominant substance produced (Fahn 1979).

The structural similarity of colleters with other secretory structures and the general lack of studies identifying their exudates have led many researchers to confuse colleters with nectaries or resin glands (Arekal \& Ramakrisna 1980, Mohan \& Inamdar 1986, Subramanian et al. 1989, Thomas 1991).

Colleters have an extremely important function in plant growth, being responsible for secretions that can protect and lubricate meristems (Fahn 1979). The

\footnotetext{
1. Part of the PhD thesis of the author, Programa de Pós-Graduação em Biologia Vegetal, Universidade Estadual de Campinas, SP, Brazil.

2. Universidade Federal do Recôncavo da Bahia, Centro de Ciências Agrárias, Ambientais e Biológicas, 44380-000 Cruz das Almas, BA, Brazil

3._Corresponding author: fmartins@ufrb.edu.br
}

material liberated by a colleter may be composed solely of mucilage (Fahn 1979, Thomas 1991) or a mixture of mucilage with lipophilic substances, including terpenoids (Fahn 1990); additional substances have been detected in colleters in the Apocynaceae such as resins (Subramanian et al. 1989), lipids (Appezzato-daGlória \& Estelita 2000), proteins (Thomas et al. 1989), mucopolysaccharides (Dave et al. 1987, Thomas et al. 1989), phenolic compounds (Rio et al. 2002, Demarco 2005, Rio 2006), and fatty acids (Demarco 2005). Only fairly reduced numbers of researchers have described the ontogeny and histochemistry of colleters, including Brazilian workers such as: Appezzato-da-Glória \& Estelita (2000), who described the development, structure, and distribution of colleters in Mandevilla illustris (Vell.) Woodson and M. pohliana (Stadelm.) A.H. Gentry ( $=$ M. velutina (Mart. ex Stadelm.) Woodson; Rio et al. (2002), who characterized the anatomy of the leaf colleters of Prestonia coalita (Vell.) Woodson; Simões et al. (2006), who described the anatomy of the calycine colleters of seven species of Apocynaceae; and Martins et al. (2010), who described the vegetative and floral colleters of Temnadenia violacea (Vell.) Miers.

In order to contribute to our knowledge about the colleters of the Apocynaceae, the present work describes the structure of the vegetative and calycine colleters of Odontadenia lutea (Vell.) Markgr. and characterizes the chemical nature of their secretions. 


\section{MATERIAL AND METHODS}

The study material was collected in two areas of Cerrado (Brazilian savanna) vegetation in the Mogi-Guaçu Biological Reserve and the Bauru Botanical Garden in São Paulo State, Brazil. Reference material was deposited in the UEC Herbarium, São PAulo: Bauru, 10/II/2004, F Martins s.n. (UEC 147884); Mogi-Guaçu, 22/II/2004, F Martins s.n. (UEC 147886); 22/II/2004, F Martins s.n. (UEC 147885); 22/II/2004, F Martins s.n. (UEC 147883).

Branches with shoot apices, leaf buds, inflorescences with floral buds at different development states, and flowers in anthesis were collected and fixed in formaldehyde-acidic acetic- 50\% ethyl alcohol, 1:1:18 v/v (FAA) for 24 hours (Johansen 1940); neutral-buffered formaldehyde solution (FNT) for 48 hours (Lillie 1948 in Clark 1973); formalinferrous sulfate (SFF) for 48 hours (Johansen 1940). All of the material was exposed to vacuum desiccation during the process of fixation and was subsequently transferred to $70 \%$ ethyl alcohol.

Samples were isolated and kept in $70 \%$ tertiary butyl alcohol for approximately 7 days, dehydrated in a butilic alcohol series, and subsequently embedded in histological paraffin (Histosec/Merck; Johansen 1940). Serial transversal and longitudinal sections (ca. $10 \mu \mathrm{m}$ ) were made in a rotary microtome. The sections were stained with $1.5 \%$ alcoholic Safranin O and 1\% aqueous Astra Blue (Gerlarch 1969); permanent slides were mounted with synthetic resin (Permount/Fisher).

Histochemical tests of the calycine colleters were performed on serial sections of floral buds ( 15 and $30 \mathrm{~mm}$ long) that were fixed: in FAA and tested for polysaccharides, proteins, or water-soluble phenolic compounds; in FNT to identify total lipids and lipid soluble phenolic compounds; in SFF to test for all classes of phenolic compounds. The treatments utilized are described in table 1 . The slides used in the histochemical tests were mounted with glycerinated gelatin.

The controls for the tests for lipophilic substances used an extraction solution composed of chloroform/methanol/ water/HCl (66:33:4:1 v/v, High 1984). The samples were immersed in this solution for 48 hours at room temperature and subsequently fixed in FAA or FNT and submitted to the same treatments as the other samples.

To identify the presence of polysaccharides in vegetative colleters, sections of the vegetative apex were fixed in FAA and treated with Ruthenium red (Gregory \& Baas 1989) or exposed to the PAS reaction (Periodic acid-Schiff; McManus 1948). The controls for these hydrophilic substances were carried out as described in the specific references.

Photomicrographs were taken using an Olympus BX51 microscope and Kodak Pro Image 100 film. The photomicrographs were digitalized using Adobe Photoshop 9.0 software. The figure scales were obtained by photographing/digitalizing a millimeter scale under the same optical conditions. Measurements of the lengths of the colleters were performed on three vegetative and floral apices from each individual using a camera lucida apparatus. The classification of the colleters followed Lersten (1974).

\section{RESULTS}

\section{Leaf colleters (figures 1-7)}

Vegetative apices approximately $5 \mathrm{~mm}$ long and having approximately seven nodes were used to describe the colleters. The colleters were found above the fourth

Table 1. List of the histochemical tests used to identify the principal metabolic compounds secreted by the calycine colleters in Odontadenia lutea (Apocynaceae - Apocynoideae - Odontadenieae).

\begin{tabular}{lll}
\hline Metabolic group & & Reagent \\
\hline Lipids & Total lipids & Sudan black B (Pearse 1985) \\
& & Sudan IV (Pearse 1985) \\
& Acidic and neutral lipids & Nile blue sulfate (Cain 1947) \\
Terpenes & Fatty acids & Copper acetate/rubeanic acid (Ganter \& Jollés 1969) \\
Phenolic compounds & Essential oils and resin oils & Nadi reagent (David \& Carde 1964) \\
& General phenolic compounds & Potassium dichromate (Gabe 1968) \\
Alkaloids & & Ferric chloride (Johansen 1940) \\
Polysaccharides & Total polysaccharides & Wagner reagent (Furr \& Mahlberg 1981) \\
& Starch & PAS reaction (McManus 1948) \\
& Acidic mucopolysaccharides & Lugol reagent (Johansen 1940) \\
& Acidic mucilage & Alcian blue (Pearse 1985) \\
Proteins & Mucilage & Ruthenium red (Gregory \& Baas 1989) \\
& Total proteins & Mayer's reagent (Pizzolato 1977) \\
& & Coomassie blue (Fisher 1968) \\
& & Bromophenol blue (Mazia et al. 1953) \\
& Aniline blue-black (Fisher 1968) \\
\hline
\end{tabular}



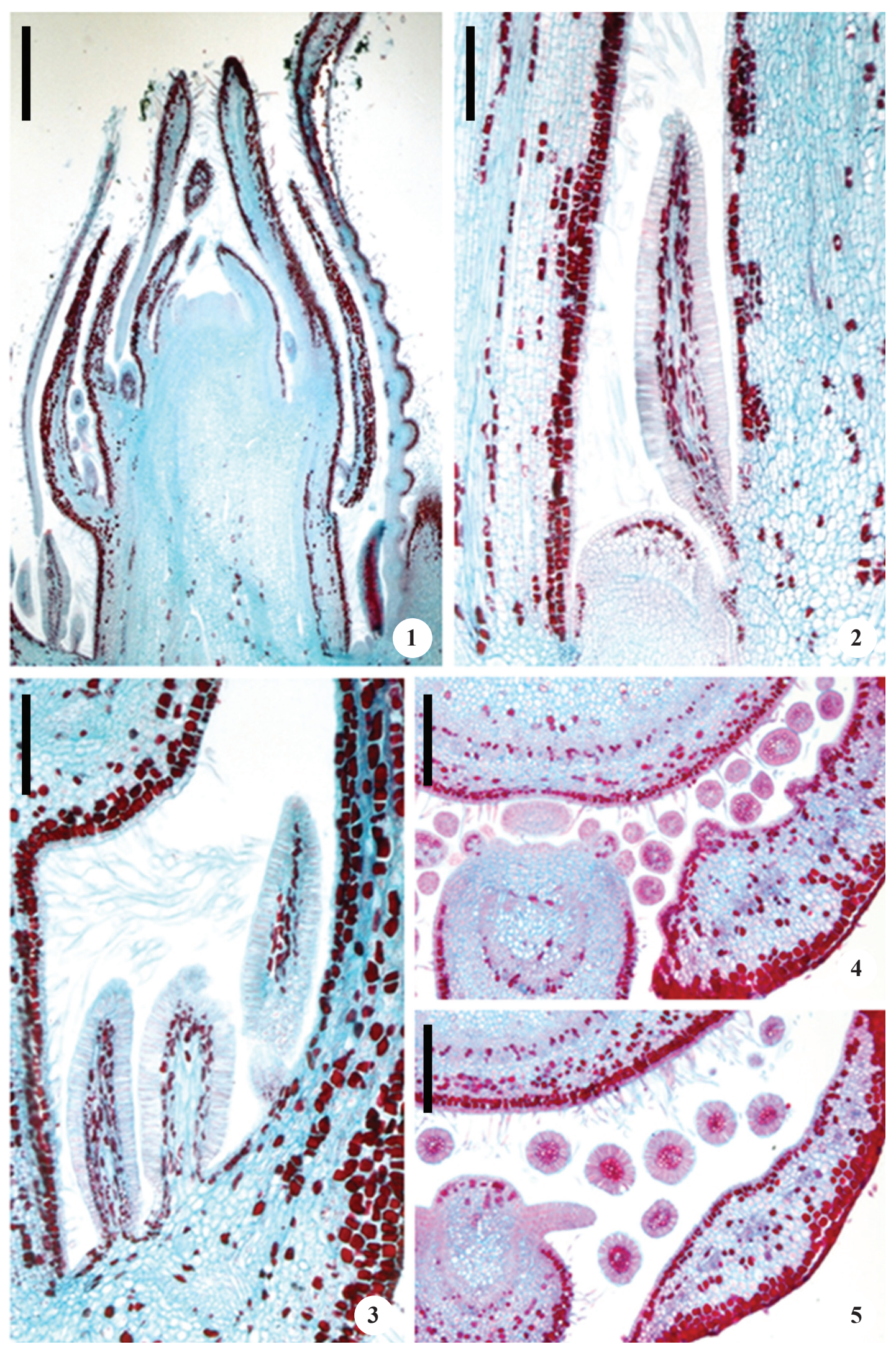

Figures 1-5. Longitudinal and transversal sections of the apical and vegetative colleters of Odontadenia lutea. 1. General view. 2. Axillary colleters. 3. Inter-petiolar (intra-stipular) colleters. 4-5. Internodal region showing median and apical portions of the inter-petiolar (intra-stipular) and axillary colleters. Bar = $100 \mu \mathrm{m}$ (1); $50 \mu \mathrm{m}(2-3) ; 200 \mu \mathrm{m}(4-5)$. 
node (figure 1); the origin and type of colleter were similar on all the nodes. Each node (figures 1-5) had 68 to 80 colleters. Each foliar primordium had one axillary colleter, 3-5 intra-petiolar colleters, and 12-16 inter-petiolar (intra-stipular) colleters (figures 2-5). The numbers of intra-petiolar and inter-petiolar (intrastipular) colleters were found to vary at different nodes along the same apex and among apices of the same individual.

Four types of colleters were seen (table 2): standard (figure 2), bipartite standard, sessile (figure 3), and bipartite sessile (figure 4), and they occupied either axillary (figure 2), intra-petiolar, or inter-petiolar (intrastipular) positions (figures 3-4). All of the colleter types were composed of a central nucleus of parenchyma cells that was covered by a uniseriate palisade secretory epidermis (figures 2-3). Crystals were observed in the parenchyma of the axillary colleter. Vascularization was only observed in standard type axillary colleters. The bipartite colleter divided after reaching two thirds of its total length, giving rise to two segments that differed only in terms of their dimensions (figure 4).

The palisade secretory epidermal cells had thin cuticle, relatively large nuclei, and dense cytoplasm. The dense cytoplasm in the parenchymatous axis of the colleters and the secretory idioblasts stained strongly with safranin.

The axillary colleter was the largest encountered (standard type) and was approximately $800 \mu \mathrm{m}$ long. The bipartite and standard intra-petiolar and inter-petiolar (intra-stipular) colleters were at most $420 \mu \mathrm{m}$ long.

Tests undertaken using Ruthenium red (figure 6) and Mayer's reagent (figure 7) indicated the presence of mucilage within the cells of the palisade epidermis.

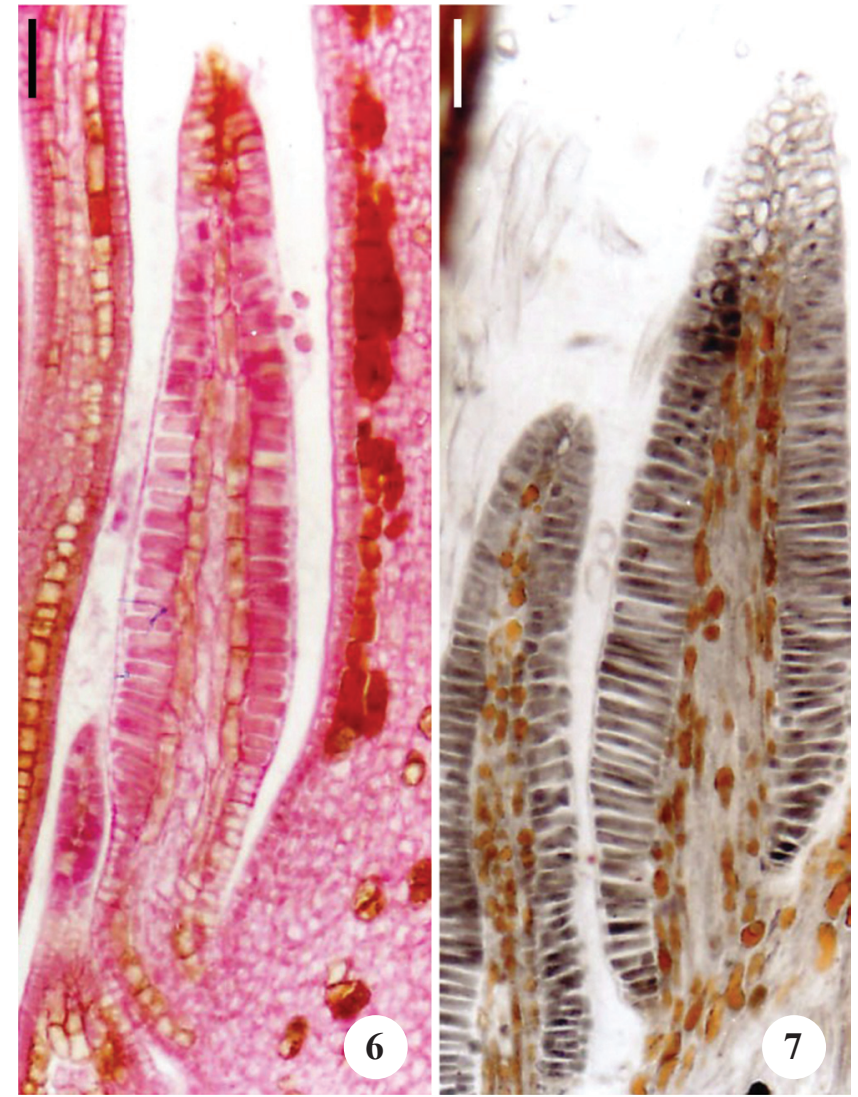

Figures 6-7. Longitudinal sections of the vegetative colleters of Odontadenia lutea. 6. Ruthenium red. 7. Mayer's reagent. Bar $=200 \mu \mathrm{m}$.

\section{Calycine colleters (figures 8-32)}

The descriptions and illustrations of the calycine colleters were derived from $15 \mathrm{~mm}$ and $30 \mathrm{~mm}$ long floral buds. These colleters originate at the base of the calyx. In O. lutea, the calyx has five unequal sepals, two

Table 2. Origin, position, and types of vegetative and calycine colleters in Odontadenia lutea (Apocynaceae - Apocynoideae Odontadenieae).

\begin{tabular}{llll}
\hline Organ & Origin & Position & Type \\
\hline Vegetative apex & Axillary & Axillary & Standard (figures 1-2) \\
& Marginal & Intra-petiolar & Sessile \\
& & Bipartite sessile \\
& & Bipartite standard \\
& & Sessile (figure 3) \\
& & Bipartite sessile \\
Reproductive apex & (intra-stipular) & Bipartite standard (figures 4-5) \\
& Marginal & Marginal & Sessile (figures 15 and 23) \\
& & Reduced sessile (figures 14 and 23) \\
& & Tripartite laminar sessile (figures 16 and 24-26) \\
& & Asymmetrical (figures 17 and 21-22) \\
\hline
\end{tabular}


external, two internal, and one imbricate, characterizing a sinistrorse quincuncinal preflowering. The colleters are found on the edges of the internal sepals and only one colleter was observed on the internal portion of the imbricate sepal. Due to their position on the edges of the sepals, the colleters can be considered alternate-sepalous (figures 8-13).

Four types of colleters (table 2) were observed on the calyx, with three types occurring on the internal sepals, and one on the internal portion of the imbricate

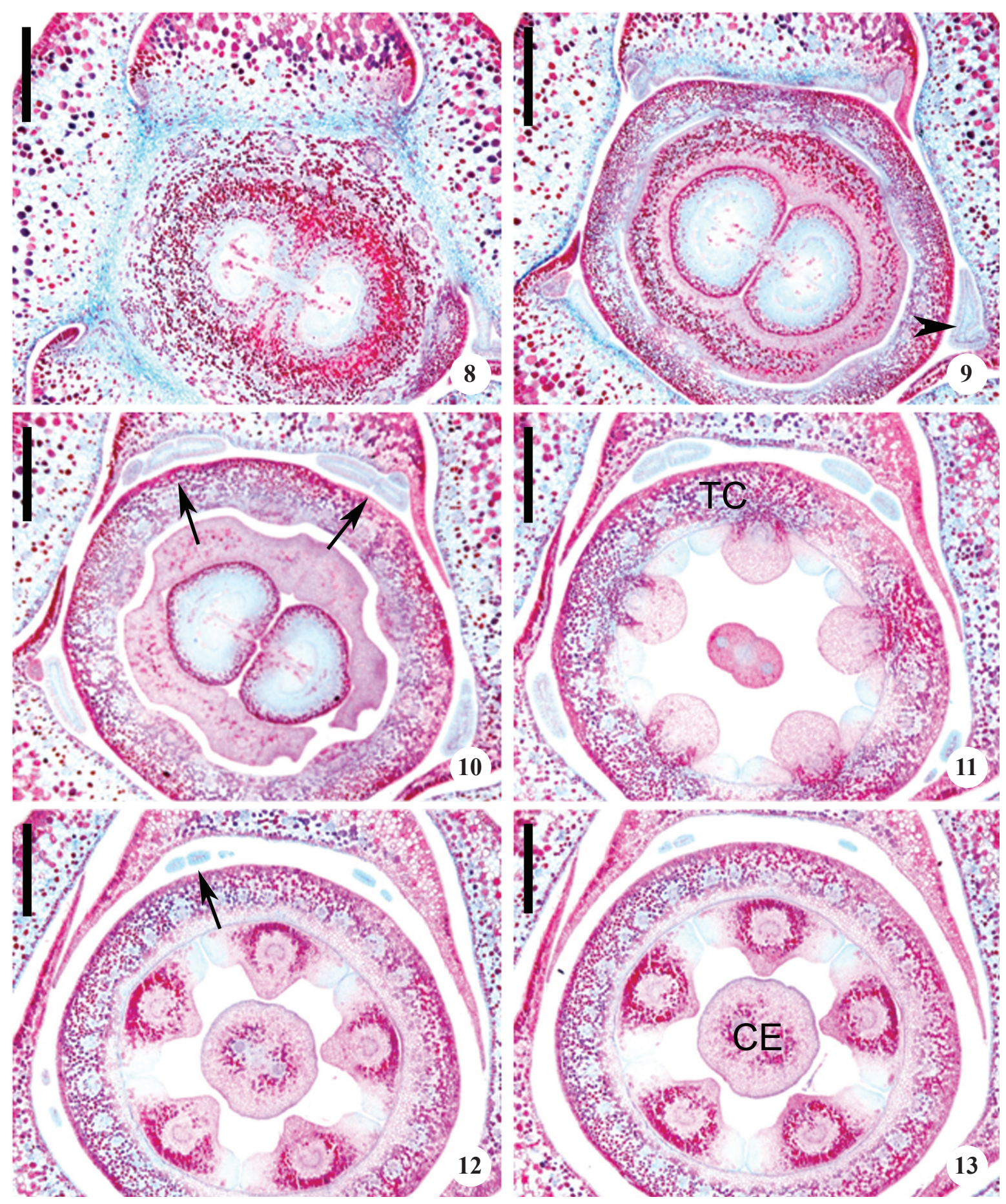

Figures 8-13. Transversal sections of the calycine colleters of Odontadenia lutea. 8. Colleters in the inner portion of the imbricate sepal. 9. Colleters at the bases of the internal parts of the calyx, asymmetrical colleters. 10-11. Tripartite laminar colleters, first portion. 12. Tripartite laminar colleters, second portion. 13. Terminal portion of a tripartite colleter. (arrow $=$ divisions of the colleters; arrowhead $=$ asymmetrical colleters; $\mathrm{CE}=$ style head; $\mathrm{TC}=$ corolla tube). $\mathrm{Bar}=100 \mu \mathrm{m}$. 
sepal. Reduced sessile colleters were observed on the edge of the internal sepal (figure 14). The second colleter type was morphologically similar to the first (although larger) and thus designated as sessile (figure 15); the third type of colleter was tripartite laminar sessile (figure 16). The fourth type of colleter occurred on the inner portion of the imbricate sepal and did not have a regular shape, thus being considered asymmetrical (figures 17-21).

All of the calycine colleters were formed from a nucleus of parenchymatous cells surrounded by a uniseriate secretory palisade epidermis and covered by a cuticle (figures 22-26). The secretory cells had thin
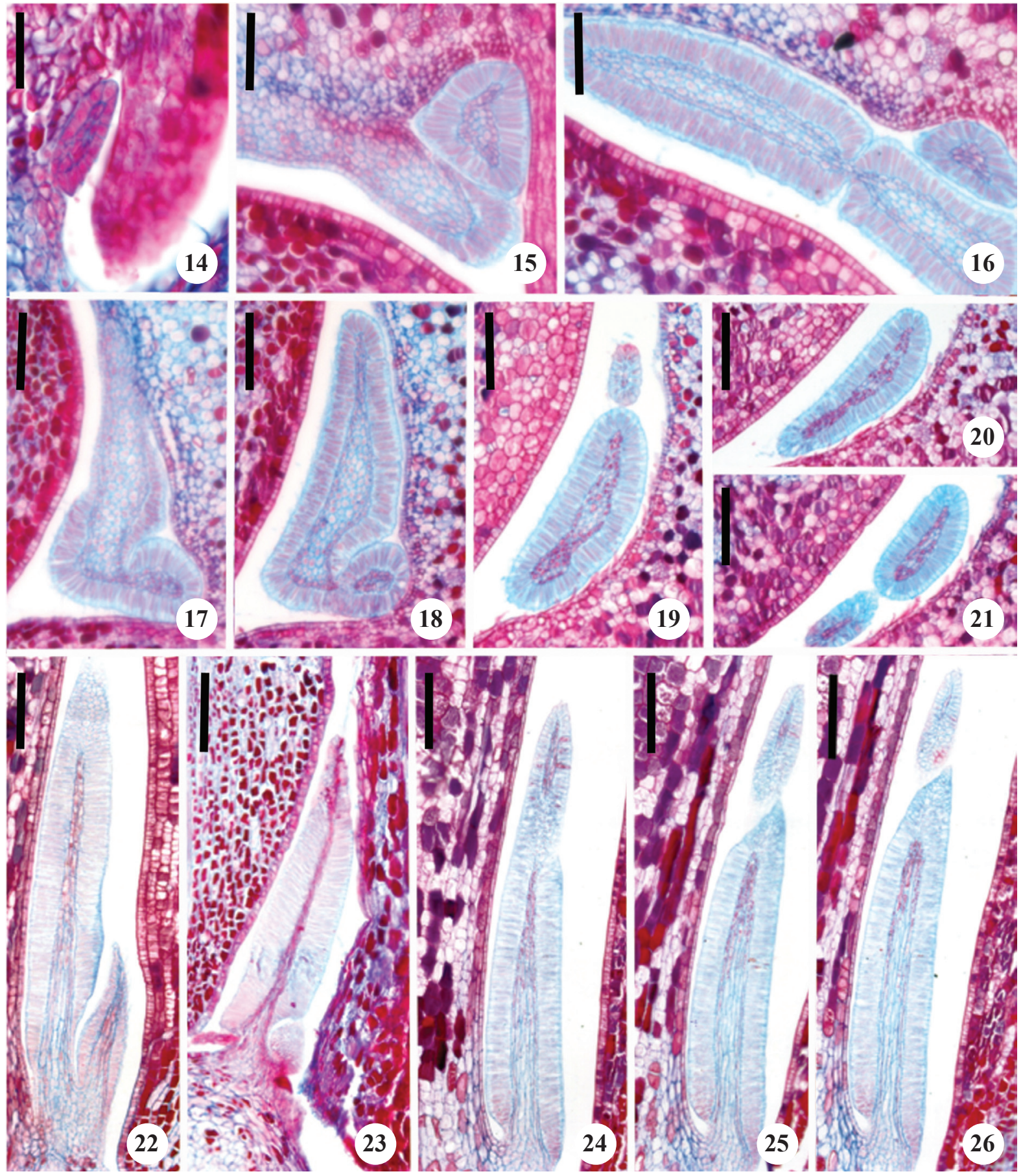

Figures 14-26. Transversal (14-21) and longitudinal (22-26) sections of the calycine colleters of Odontadenia lutea. 14. Reduced sessile colleter. 15. Sessile colleter. 16. Tripartite laminar sessile colleter. 17-21. Asymmetrical colleter, note separation of the larger portion into three sections. 22. Asymmetrical colleter. 23. Sessile colleter and reduced sessile colleter. 24-26. Detail of the sections of a tripartite laminar sessile colleter. $\mathrm{Bar}=200 \mu \mathrm{m}$. 
walls, evident nuclei, and dense cytoplasm. Vascular tissue was only observed in laminar colleters.

Histochemical tests indicated that the cuticle did not rupture during secretion (figures 27-32). It was also possible to verify that the cuticle did not become distended, with the secretion apparently accumulating in this space between the external periclinal wall and the protoplast (figure 27). Secretion was visible in the

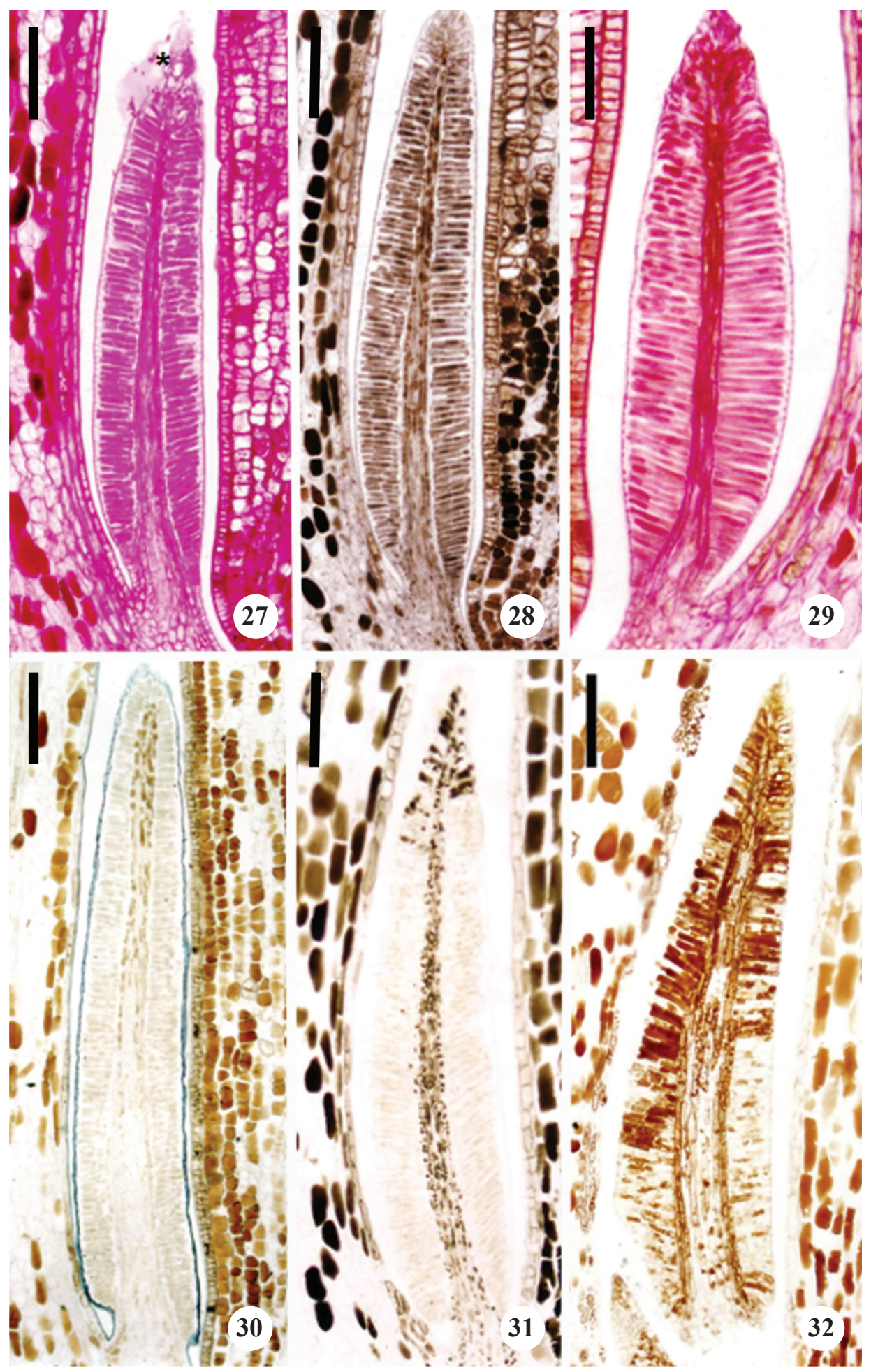

Figures 27-32. Histochemical tests of the calycine colleters of Odontadenia lutea in longitudinal sections. 27. PAS reaction. 28. Mayer's reagent. 29. Ruthenium red. 30. Sudan black B, note a positive reaction only in the cuticle. 31. Ferric chloride. 32. Potassium dichromate. Bar $=200 \mu \mathrm{m}$. 
interior of the secretory epidermal cells of buds that were $15 \mathrm{~mm}$ long, as well as accumulated outside these structures and lubricating the buds in the external medium of the colleters on buds that were $30 \mathrm{~mm}$ long.

The results of the histochemical tests designed to detect the presence of water-soluble and lipid-soluble substances are presented in table 3. Mucilage was identified in $15 \mathrm{~mm}$ and $30 \mathrm{~mm}$ buds by its reactions with PAS (figure 27), Mayer's reagent (figure 28), and
Ruthenium red (figure 29). Mucilage is less evident in more developed buds, indicating a decrease (or even a cessation) of its secretion in a later phase. Phenolic compounds were observed using ferric chloride and potassium dichromate (figures 31-32) only in the colleters of buds that were $30 \mathrm{~mm}$ long. Calycine colleters thus demonstrated two distinct secretory phases, the first with synthesis of mucilage and a second phase in which phenolic compounds are produced.

Table 3. Results of the histochemical tests applied to calycine and floral bud (15 mm and $30 \mathrm{~mm}$ long) colleters in Odontadenia lutea (Apocynaceae - Apocynoideae - Odontadenieae) $(-=$ negative $;+=$ positive $)$.

\begin{tabular}{llcc}
\hline \multirow{2}{*}{ Treatments } & Substances to be detected & \multicolumn{2}{c}{ Results } \\
\cline { 3 - 3 } & & $15 \mathrm{~mm}$ & $30 \mathrm{~mm}$ \\
\hline PAS reaction & Total polysaccharides & + (figure 27) & + \\
Mayer`s reagent & Mucilage & + (figure 28) & + \\
Ruthenium red & Acidic mucilage & + (figure 29) & - \\
Alcian blue & Acidic mucopolysaccharides & - & - \\
Lugol reagent & Starch & - & - \\
Coomassie blue & Total proteins & - & - \\
Bromophenol blue & Total proteins & - & - \\
Aniline blue-black & Total protein & - & - \\
Sudan black B & Total lipids & - (figure 30) & + \\
Sudan IV & Total lipids & + & + \\
Nile blue sulfate & Acidic and neutral lipids & - & - \\
Copper acetate/ rubeanic acid & Fatty acid & - & - \\
Nadi reagent & Terpenes & - & - \\
Ferrous sulfate in formaldehyde & Total phenolic compound & - & + \\
Ferric chloride & Phenolic compounds & - & + (figure 31) \\
Potassium dichromate & Phenolic compounds & - & + (figure 32) \\
Wagner reagent & Alkaloids & - & - \\
\hline
\end{tabular}

\section{DISCUSSION}

Colleters are frequently seen on vegetative and reproductive structures in Apocynaceae (Thomas 1991) and have been reported in 25 genera of the Apocynoideae (Endress \& Bruyns 2000).

The genus Odontadenia demonstrates a common characteristic for the family - the presence of interpetiolar stipules - and large numbers of colleters have been observed on these structures. Woodson \& Moore (1938) proposed that colleters are derived from stipules in many species of Apocynaceae and they considered colleters as a category of stipules - with the retention of a vascular system, such as seen in Mandevilla illustris and M. pohliana (Stadelm.) A.H.Gentry (= M. velutina (Mart. ex Stadelm. Woodson, Appezzato-da-Glória \& Estelita 2000) and in Prestonia coalita (Rio et al. 2002). The numerous colleters in $O$. lutea originate on the adaxial face of an inter-petiolar stipule. The occurrence of these colleters on stipules has not been previously described in Apocynaceae and they are therefore denominated intrastipular colleters.

Variations in the numbers of vegetative colleters have been observed, and occur quite frequently in Apocynaceae (Ramayya \& Bahadur 1968, Fjell 1983, Thomas \& Dave 1989a, Thomas 1991). According to Thomas (1991), the number of colleters in a single species can vary according to its geographic distribution, indicating that this character is plastic and of little taxonomic value. This large variation in the number of colleters is normal, and reflects the high number of colleters that can occur at a single node.

In terms of the size of the colleters, large variations were seen in their length independent of their origin or position (whether inter- or intra-stipular). Lersten (1975) studied more than 296 species of Rubiaceae from different 
continents and often observed considerable differences in the size of colleters on the same species.

A noticeable character encountered in Odontadenia lutea was the occurrence of four types of colleters on the same floral bud that developed asynchronously. A similar ontogenetic study undertaken with Blepharodon bicuspidatum Fourn. identified the asynchronous initiation of vegetative colleters (Demarco 2005).

Bifurcated colleters have been described from the floral buds of Temnadenia violacea (Martins et al. 2010), Prestonia coalita (Rio 2001), Forsteronia (Rio 2006), Mandevilla pycnantha (Steud. ex A.DC.) Woodson, and M. tenuifolia (Simões et al. 2006). There is considerable confusion surrounding the terminology utilized to describe colleters, and in many cases tripartite and fimbriate colleters are synonymized. According to Simões et al. (2006), the terminology traditionally used to describe calycine colleters in Apocynaceae is confusing, and adjustments are needed to avoid equivocal interpretations. These authors proposed typologies derived from a standard colleter, using the fundamental mechanisms of cell separation, proliferation, and elongation to describe them. As such, bifurcate and fimbriate colleters originate from the separation of distinct portions of the colleter axis.

The first classification of colleters was undertaken by Lersten (1974), based on the typologies encountered in Rubiaceae - without contemplating any of the forms described for Apocynaceae - which resulted in equivocal interpretations for this and other families. In spite of the proximity of the families Apocynaceae and Rubiaceae, there is an enormous divergence in the types of colleters encountered in each; dendritic colleters are consistently observed in Rubiaceae (Lersten 1974) for example, but are completely absent in Apocynaceae.

The occurrence of different types of colleters on the reproductive and vegetative organs of the same species runs contrary to the theory proposed by Woodson \& Moore (1938). These authors assumed that foliar and calycine colleters are structurally homologous and that the alternate-sepal positions of the calycine colleters are similar to those of the vegetative nodes in relation to the petiole. If the stipules of $O$. lutea do in fact correspond to calycine colleters, this would support the theory of Woodson \& Moore (1938); however, it is difficult to explain the absence of colleters on the external portion of the imbricate sepal as a structural variation of calycine colleters. It is possible that the occurrence of asymmetrical colleters is related to the fusion of tripartite laminar colleters and reduced sessile colleters.

The presence of vascular tissue associated with colleters has been observed in various species of
Apocynaceae and in many cases this is due to the retention of stipule vascularization, as in Prestonia coalita (Rio et al. 2002). Vascularized colleters have been reported in Wattakaka volubilis Stapf. (Arekal \& Ramakrishna 1980), Aganosma caryophyllata G. Don (Dave et al. 1987), Mandevilla illustris, and $M$. pohliana (Appezzato-da-Glória \& Estelita 2000). However, many species of Apocynaceae do not have any vascularized colleters, such as Allamanda neriifolia Hook., Thevetia peruviana Merr., Vinca minor Sm. (Fjell 1983), Allamanda cathartica Schrad. (Thomas \& Dave 1989a), and Roupelia grata Wall. (Thomas et al. 1989). Vascularization in Odontadenia lutea occurs only in the axillary colleter of the stem apex and on the laminar colleter of the floral apex. According to Demarco (2005), the presence of vascular tissue can vary among the different types of colleters present on the same organ. Appezzato-da-Glória \& Estelita (2000) reported that the inter-petiolar colleters of Mandevilla Lindl. were vascularized, while the foliar colleters could be associated with vascular tissue, or not. Woodson \& Moore (1938) consider the absence of vascularization as a predominant characteristic of the calycine colleters of Apocynaceae species.

Vascularization was observed among the largest colleters of O. lutea. Carlquist (1969) noted that the vascular tissue associated with any structure is directly proportional to its size, and not necessarily related to its developmental state. According to Appezzato-daGlória \& Estelita (2000), the vascularization of petiolar or axillary colleters is independent of their size, while Martins et al. (2010) observed vascularization only among the largest vegetative colleters of Temnadenia violacea, corroborating the point of view of Carlquist (1969).

Idioblasts appear to be common features in Apocynaceae, and they have been observed in various organs of the same plant (Metcalfe \& Chalk 1950, 1983). As such, the presence of idioblasts in vegetative and calycine colleters in this family is not surprising, as was seen in O. lutea. Crystal-containing idioblasts were observed in Roupelia grata (Thomas et al. 1989) and Thevetia peruviana (Fjell 1983) and tannin-containing idioblasts were reported in Himatanthus Willd. ex Roem. \& Schult. (Barros 1988), Mandevilla illustris, and $M$. pohliana (Appezzato-da-Glória \& Estelita 2000) as well as in the vegetative colleters of Forsteronia glabrescens Müll. Arg., F. pubescens DC. And F. thyrsoidea Müll. Arg. (Rio et al. 2005).

The liberation of accumulated secretions from the periplasmic space to the external environment most likely occurs through the cell wall and cuticle, as no 
distention or rupturing of the cuticle was observed. This same manner of exudate liberation was attributed to the vegetative colleters of Blepharodon bicuspidatum (Demarco 2005).

Colleters are structures that produce viscose secretions of mucilage (Fahn 1979, Thomas 1991) or mixtures of mucilage and lipophilic substances (Fahn 1979). Thomas (1991) attributed colleters with the function of protecting plant meristems, which is supported by the nature of those secretions. The presence of mucilage on the developing meristem helps to prevent desiccation in a region with a very thin cuticle. Mucilage has been detected in the colleters of Plumeria rubra L. (Mohan \& Inamdar 1986), Roupelia grata (Thomas et al. 1989), Allamanda cathartica (Thomas \& Dave1989a), Mandevilla illustris and M. pohliana (Appezzato-da-Glória \& Estelita 2000), Prestonia coalita (Rio 2001), Blepharodon bicuspidatum (Demarco 2005), Forsteronia glabrescens (Rio 2006), and Temnadenia violacea (Martins et al. 2010)

Mucilage, however, is also attractive to opportunistic organisms such as fungi and bacteria that can cause structural damage to the meristem. In various species of Rubiaceae, nodulation processes provoked by bacteria in apical meristems have been noted (Lersten 1974, 1975), which would indicate an intimate relationship between the host and nodule species, resulting in benefits for both through a symbiotic relationship. One way to avoid deleterious contamination would be to have a second secretion phase with exudates containing phenolic compounds. According to Harbone (1988), phenolic compounds aid in preventing infections in plants provoked by fungi and bacteria. The secretion of phenolic compounds during a second secretory phase has been observed in Roupelia grata (Thomas et al. 1989), Forsteronia glabrescens (Rio 2006), and Temnadenia violacea (Martins et al. 2010). The secretion of mucilage and phenolic compounds occur simultaneously in the foliar and calycine colleters of Blepharodon bicuspidatum (Demarco 2005).

The genus Odontadenia Benth. A. DC. was recently reassigned by Livshultz et al. (2007) to a new tribe composed of five genera, although only Secondatia has been anatomically studied (Simões 2004). This new organization was based on recent molecular information and floral morphological studies, without considering vegetative characteristics or their vegetative and calycine colleters. In describing the floral anatomy of $O$. lutea and S. densiflora, Martins (2008) observed morphological characteristics indicating similarities between these two species, although their vegetative and calycine colleters are quite divergent.
Acknowledgments - The author would like to thank Capes for the PhD grant and the Fundação de Amparo a Pesquisa do Estado de São Paulo (Fapesp) for its aid to this project (Biota/Fapesp proc. 00/12469-3).

\section{REFERENCES}

Appezzato-da-Glória B, Estelita MEM. 2000. Development, structure and distribution of colleters in Mandevila illustris and $M$. velutina (Apocynaceae). Revista Brasileira de Botânica 23:113-120.

Arekal GD, Ramakrishna TM. 1980. Extrafloral nectaries of Caloptropis gigantea and Wattakaka volubilis. Phytomorphology 30:303-306.

Barros CF. 1988. Himatanthus lancifolius (Muell-Arg) Woodson (Apocynaceae): Anatomia foliar. Rodriguésia 64/66:25-31

Cain AJ. 1947. The use of Nile Blue in the examination of lipids. Quarterly Journal of Microscopical Science 88:383-392.

Carlquist S. 1969. Toward acceptable evolutionary interpretations of floral anatomy. Phytomorphology 19:332-362.

Clark G. 1973. Staining procedures. 3rd ed. The Williams \& Wilkins Co., Baltimore.

Dave Y, Thomas V, Kuriachem PM. 1987. Structure and development of colleteres in Aganosma caryophyllata. Pakistan Journal of Botany 19:243-248.

David R, Carde JP. 1964. Coloration différentielle des inclusions lipidique et terpeniques des pseudophylles du Pin maritime au moyen du reactif Nadi. Comptes Rendus de L'Academie des Sciencies (Paris), Série D 258:1338-1340.

Demarco D. 2005. Estruturas secretoras florais e coléteres foliares em espécies de cerrado de Aspidosperma Mart. e Blepharodon Decne (Apocynaceae s.l.). Tese de mestrado, Universidade Estadual de Campinas, Campinas.

Endress ME, Bruyns PV. 2000. A revised classification of Apocynaceae s.l. Botanical Review 66:1-56.

Fahn A. 1979. Secretory tissues in plants. Academic Press Inc., London.

Fahn A. 1990. Plant anatomy. Pergamon Press, Oxford.

Fisher DB. 1968. Protein staining of ribboned epon sections for light microscopy. Histochemie 16:92-96.

Fjell I. 1983. Anatomy of the xeromorphic leaves of Allamanda neriifolia, Thevetia peruviana and Vinca minor (Apocynaceae). Nordic Journal of Botany 3: 383-392.

Furr M, Mahlberg PG. 1981. Histochemical analyses of lacticifers and glandular trichomes in Cannabis sativa. Journal of Natural Products 44:153-159.

Gabe M. 1968. Techniques histologiques. Masson \& Cie, Paris.

Ganter P, Jollés G. 1969. Histologie normale et pathologique. v.I-II. Gauthier-Villars, Paris. 
Gerlarch D. 1969. Botanische Mikrotechnik: Eine Einführung. Georg Thieme, Stuttgart.

Gregory M, Baas P. 1989. A survey of mucilage cells in vegetative organs of the dicotyledons. Israel Journal of Botany 38:125-174.

Harbone JB. 1988. Introduction to ecological biochemistry. Academic Press, London.

High OB. 1984. Lipid histochemistry. Oxford University Press, New York.

Johansen DA. 1940. Plant microtechnique. McGraw-Hill, New York.

Lersten NR. 1974. Morphology and distribution of colleters and crystals in relation to the taxonomy and bacterial leaf nodule symbiosis of Psychotria (Rubiaceae). American Journal of Botany 61:973-981.

Lersten NR. 1975. Colleter types in Rubiaceae, especially in relation to the bacterial leaf nodule symbiosis. Botanical Journal of Linnean Society 71:311-319.

Livshults T, Middleton DJ, Endress ME, Williams JK. 2007. Phylogeny of Apocynoideae and the APSA Clade (Apocynaceae s.l.). Annals of the Missouri Botanical Garden 94:342-359.

Martins FM. 2008. Glândulas foliares e florais em três espécies de Apocynaceae - Apocynoideae de cerrado. Tese de doutorado, Universidade Estadual de Campinas, Campinas.

Martins FM, Kinoshita L, Castro M de M. 2010. Coléteres foliares e calicinais de Temnadenia violacea (Vell.) Miers (Apocynaceae, Apocynoideae): estrutura e distribuição. Revista Brasileira de Botânica 33:519-530.

Mazia D, Brewer PA, Alfert M. 1953. The cytochemistry staining and measurement of protein with mercuric bromophenol blue. Biological Bulletin 104:57-67.

McManus JFA. 1948. Histological and histochemical uses of periodic acid. Stain Technology 23:99-108.

Metcalfe CR, Chalk L. 1950. Anatomy of the dicotyledons: leaves, stem and wood in relation to taxonomy with notes on economic uses. Clarendon Press, Oxford.

Metcalfe CR, Chalk L. 1983. Anatomy of the dicotyledons. Wood structure and conclusion of the general introduction. Clarendon Press, Oxford.

Mohan JSS, Inamdar JR. 1986. Ultrastructure and secretion of extrafloral nectarines of Plumeria rubra L. Annals of Botany 57:389-401.

Pearse AGE. 1985. Histochemistry: theorical and applied. v.II. Livingstone, Edinburgh.

Pizzolato TD. 1977. Staining of Tilia mucilages with Mayer's tannic acid-ferric chloride. Bulletin of the Torrey Botanical Club 104:277-279.

Pizzolato TD, Lillie RD. 1973. Mayer's tannic acid-ferric chloride stain for mucins. Journal of Histochemistry and Cytochemistry 21:56-64.

Ramayya N, Bahadur B. 1968. Morphology of the "squamellae" in the light of their ontogeny. Current Science 18:520-522.
Rao VS, Ganguli A. 1963. Studies in the floral anatomy of the Apocynaceae. Journal of the Indian Botanical Society 42:419-435.

Rio MCS. 2001. Estudos taxonômicos e anatômicos do gênero Prestonia R.BR. nom. cons. (Apocynaceae). Tese de mestrado, Universidade Estadual de Campinas, Campinas.

Rio MCS. 2006. Estudos anatômicos em espécies de Forsteronia G.Mey (Apocynaceae) de cerrado. Tese de doutorado, Universidade Estadual de Campinas, Campinas.

Rio MCS do, Castro M de M, Kinoshita LS. 2002. Distribuição e caracterização anatômica dos coléteres foliares de Prestonia coliata (Vell.) Woodson (Apocynaceae). Revista Brasileira de Botânica 25:339-349.

Rio MCS, Kinoshita LS, Castro M de M. 2005. Anatomia foliar como subsídio para a taxonomia de espécies de Forsteronia G.Mey. (Apocynaceae) dos cerrados paulistas. Revista Brasileira de Botânica 28: 713-726.

Schnepf E. 1974. Gland cells. In Dynamic aspects of plant ultrastructure (AW Robards, ed.) MacGraw-Hill Book Co., Maidenhead.

Simões AO. 2004. Estudos filogenéticos e anatômicos da tribo Mesechiteae Miers (Apocynaceae, Apocynoideae). Tese de doutorado, Universidade Estadual de Campinas, Campinas.

Simões AO, Castro M de M, Kinoshita LS. 2006. Calycine colleter of seven species of Apocynaceae (Apocynoideae) from Brazil. Botanical Journal of the Linnean Society 152:387-398.

Subramanian RB, Murugan V, Mohan JSS, Inamdar JA. 1989. Optical microscopic studies on the structure and secretions of resin glands in some Apocynaceae. Proceedings of Indian Academy Sciences (Plant Sciences) 99:423-429.

Thomas V. 1991. Structural, functional and phylogenetic aspects of the colleter. Annals of Botany 68:287-305.

Thomas V, Dave Y. 1989a. Histochemistry and senescence of colleter of Allamanda cathartica L. (Apocynaceae). Annals of Botany 64:201-203.

Thomas V, Dave Y. 1989b. Structure, origin, development and senescence of colleters in Nerium indicum Mill. (N. odorum Soland Apocynaceae). Korean Journal of Botany 32:163-172.

Thomas V, Dave Y. 1991. Comparative and phylogenetic significance of colleters in Apocynaceae. Feddes Repertorium 102:23-28.

Thomas V, Dave Y, Menon ARS. 1989. Anatomy and hystochemistry of colleters in Roupelia grata (Apocynaceae). Nordic Journal of Botany 8:493-496.

Woodson RE, Moore JA. 1938. The vascular anatomy and comparative morphology of apocynaceous flowers. Bulletin of the Torrey Botanical Club 65: 135-165. 